\title{
Effectiveness of Insecticides to Control Small and Large Larvae of Helicoverpa armigera (Hübner, 1805) (Lepidoptera: Noctuidae)
}

\author{
M. C. S. Vieira ${ }^{1}$, E. C. S. Vieira ${ }^{1}$, P. G. Silva ${ }^{1}$, I. F. da Silva ${ }^{1}$, C. J. Ávila ${ }^{2}$, N. D. R. da Silva ${ }^{3}$, I. C. Vessoni ${ }^{4}$ \\ \& G. F. Rodrigues ${ }^{1}$ \\ 1 Programa de Pós-graduação em Entomologia e Conservação da Biodiversidade, Universidade Federal da \\ Grande Dourados, Dourados, MS, Brazil \\ ${ }^{2}$ Empresa Brasileira de Pesquisa Agropecuária, Dourados, MS, Brazil \\ ${ }^{3}$ Instituto Federal de Mato Grosso do Sul, Nova Andradina, Brazil \\ ${ }^{4}$ Centro Universitário da Grande Dourados, Dourados, Brazil \\ Correspondence: M. C. S. Vieira, Programa de Pós-graduação em Entomologia e Conservação da Biodiversidade, \\ Universidade Federal da Grande Dourados, Dourados, MS, Brazil. Tel: 55-66-99671-0039. E-mail: \\ marikavalcante@gmail.com
}

Received: March 8, 2020

Accepted: April 11, $2020 \quad$ Online Published: May 15, 2020

doi:10.5539/jas.v12n6p90

URL: https://doi.org/10.5539/jas.v12n6p90

The research is financed by CAPES and EMBRAPA.

\begin{abstract}
Helicoverpa armigera (Hübner, 1805) (Lepidoptera: Noctuidae) is a cosmopolitan pest with wide geographical distribution in Brazil. This pest was officially registered in 2013 on cotton, soybean, corn, and some weeds, although this species may have been present in the country since 2008. The objective of this work was to evaluate the efficiency of eight insecticides (seven chemicals and a biological product) to control small and large $H$. armigera caterpillars. The experiment was conducted under laboratory conditions (T $22 \pm 1{ }^{\circ} \mathrm{C} ; \mathrm{RH} 70 \pm 10 \%$; $12 \mathrm{~h}$ photoperiod), with nine treatments ( $\mathrm{g}$ a.i./ha dose): flubendiamide (72), chlorantraniliprole + lambda-cyhalothrin $(30+15)$, chlorfenapyr (288), spinetoran (18), indoxacarb (120), emamectin benzoate (10), metomil (322.5), Bacillus thuringiensis (500), and control (water). A completely randomized design was used with four replications for each size of caterpillars (small and large), and each repetition (plot) consisted of five $H$. armigera caterpillars fed with bean leaves immersed in the different treatments evaluated. The larval mortality evaluations were performed at one, three, five, and seven days after contact with the treated bean leaves, determining the control efficiency (E\%) through the formula of Abbott (1925). All chemical and biological treatments tested caused significant mortality of small and large $H$. armigera caterpillars, reaching a control percentage of $100 \%$ at seven days after treatment, demonstrating the possibility of using the insecticides tested to control this pest under field conditions.
\end{abstract}

Keywords: insecticide, larval mortality, control efficiency, Heliothinae

\section{Introduction}

Helicoverpa spp. caterpillars are considered economically important pests for several cultivated plant species around the world. The species Helicoverpa armigera (Hübner, 1805) (Lepidoptera: Noctuidae) is among the most relevant because it is an extremely polyphagous pest, as it has already been found feeding on more than 170 host plants from different families (Cunningham \& Zalucki, 2014), including the following crops: soybean Glycine max L., cotton Gossypium hirsutum L., corn Zea mays L., wheat Triticum aestivum L., rice Oryza sativa L., oat Avena sativa L., sorghum Sorghum bicolor L., common bean Phaseolus vulgaris L., peanut Arachis hypogaea L., sunflower L., tomato Lycopersicon esculentum L., potato Solanum tuberosum L., and pigeon pea Cajanus cajan L. (Kuss et al., 2016).

Its key pest status in several crops is mainly due to the fact that $H$. armigera larvae are able to feed on both their reproductive and vegetative although they have a higher preference for the first ones (Ávila et al., 2013). It has a high capacity to adapt to adverse conditions and a high reproductive potential compared to other lepidopteran 
species (Mironidis et al., 2009; Naseri et al., 2009a, 2009b). In addition, adults can migrate over a thousand kilometers especially using night flights (Silva et al., 2018). Management of H. armigera is required throughout the entire development period of the host plants, due to its high reproductive and consumption capacity. The attack by large caterpillars is commonly observed in formed reproductive structures, enhancing the damage caused by this pest (Ávila et al., 2013). To control H. armigera caterpillars, several chemical molecules are available on the world market that can be used in different crops (Noorani et al., 1994; Abdul et al., 2003; David et al., 2005; Ávila et al., 2013). Active ingredients including lambda-cyhalothrin, methomyl, and emamectin benzoate are widely used to control this pest in several countries (Avilla \& Gonzalez-Zamora, 2010; Babariya et al., 2010). However, to control H. armigera in Brazil, there is a lack of products registered for its management, as well as few works developed under Brazilian conditions. As this pest was detected in the Cerrado region at population levels never before registered and causing serious economic damage, several products were made available by the Brazilian Ministry of Agriculture, Livestock, and Food Supply (MAPA-Ministério da Agricultura e Pecuária), for emergency control (EMBRAPA, 2013). However, the use of these products should always be done in accordance with the recommended doses and insect population levels in the field, as $H$. armigera has demonstrated the potential to develop resistance to various commercial chemical products (Ahmad et al., 2001; Fathipour \& Sedaratian, 2013).

In addition to the available chemical insecticides, biological products are also part of the strategy to control this pest, mainly due to the increase of environmental problems arising from the misuse of synthetic chemicals, as well as the demand for development of a more sustainable and environmentally friendly agriculture. The main advantage being the absence of residues in agricultural products and the environment (Oliveira \& Ávila, 2010). Thus, the use of chemical and biological insecticides is an important tool for insect pest management in various crops. Although insecticides used to control H. armigera caterpillars can prevent economic damage, a loss of efficiency has been observed as reported by Chankapue et al. (2014).

Therefore, the objective of this study was to evaluate the control efficiency of seven chemical and a biological insecticide to control small and large H. armigera caterpillars under laboratory conditions.

\section{Material and Methods}

The experiment was conducted in the Entomology laboratory of Embrapa Western Agriculture, located in Dourados, MS (22 $\left.14^{\prime} \mathrm{S} 54^{\circ} 49^{\prime} \mathrm{W}\right)$. The bean cultivar Phaseolus vulgaris L. "BRS Estilo" was planted in five liter plastic pots containing a 1:1:1 mixture of soil, sand, and organic substrate, kept in a greenhouse. After the emergence of bean plants and the unfolding of third trifoliate leaf, these leaves were removed from the plants, sanitized, and cut into leaf disks with an area of $12.56 \mathrm{~cm}^{2}$, using a metal punch.

Subsequently, the leaf disks were immersed in the insecticidal spray containing different treatments with their respective doses (Table 1) for approximately five seconds and then removed from the spray and put for drying on paper towels. These leaf discs were then offered to small and large $H$. armigera caterpillars kept in Petri dishes $(6.0 \mathrm{~cm}$ diameter $\times 1.3 \mathrm{~cm}$ height) for a period of seven days. The leaf discs were replaced in the Petri dish when necessary, depending on the degree of consumption by the caterpillars.

The experiment was carried out in a completely randomized design with nine treatments: seven chemical insecticides, a biological, and control (without insecticide) in four replications. Each experimental unit (repetition) consisted of five small $(<1.5 \mathrm{~cm})$ or large $(>1.5 \mathrm{~cm}) \mathrm{H}$. armigera caterpillars. Helicoverpa armigera caterpillars, used in the bioassay, originated from the stock maintained on artificial diet in the Entomology laboratory of Embrapa Western Agriculture, as described by Vieira et al. (2018).

Mortality assessments of small and large larvae were performed at one, three, five, and seven days after leaf disc immersion (DAI) in the different treatments, to determine the number of dead caterpillars $(\mathrm{N})$ after contact with untreated or treated leaf discs. The control efficiency (E\%) in each treatment was calculated using Abbott's formula (1925). The mortality data obtained were submitted to analysis of variance and the means of treatments compared by Tukey test at $5 \%$ probability. 
Table 1. Chemical and biological treatments ( $\mathrm{g}$ a.i./ha) used to the control of small and large caterpillars of Helicoverpa armigera (Hübner, 1805) under laboratory conditions. Dourados/MS, 2019

\begin{tabular}{|c|c|c|c|c|}
\hline Treatments & Dose (g a.i./ha) & Chemical group & Commercial name & Group/mode of action ${ }^{1}$ \\
\hline Flubendiamide & 72.0 & Phthalic Acid Diamide & $\mathrm{Belt}^{\mathbb{B}} 480 \mathrm{SC}$ & G28 \\
\hline Chlorantraniliprole + lambda-cyhalothrin & $30.0+15.0$ & Diamide + Pyrethroid & Ampligo $^{\circledR} 100+50 \mathrm{SC}$ & G3 \\
\hline Chlorfenapyr & 288.0 & Pyrazole Analog & Pirate $^{\circledR} 240$ SC & G13 \\
\hline Espinetoram & 18.0 & Spinosinas & Exalt $^{\circledR} 120 \mathrm{SC}$ & G5 \\
\hline Indoxacarb & 120.0 & Oxadiazine & $\operatorname{Avatar}^{\circledR} 150 \mathrm{EC}$ & G22 \\
\hline Emamectin Benzoate & 10.0 & Avermectin & Proclaim $^{\circledR} 50 \mathrm{SG}$ & G6 \\
\hline Metomil & 322.5 & Oxime Methyl Carbamate & Lannate $\mathrm{BR}^{\circledR} 215 \mathrm{SL}$ & G1 \\
\hline Bacillus thuringiensis & 500.0 & Biological & Agree $^{\circledR} 500 \mathrm{WP}$ & G11 \\
\hline Control & - & - & - & - \\
\hline
\end{tabular}

Note. ${ }^{1}$ classification of groups and mode of action of insecticides according to IRAC (2019).

${ }^{\mathrm{G} 28}$ ryanodine receptor modulators; ${ }^{\mathrm{G} 3}$ modules of sodium channels; ${ }^{\mathrm{G} 13}$ oxidative phosphorylation decouplers via proton gradient interruption; ${ }^{\mathrm{G} 5}$ allosteric Acetylcholine Receptor Modulators (nAChR); ${ }^{\mathrm{G} 22}$ voltage-dependent sodium channel blockers; G6 allosteric Modules of Glutamate Chloride (GluCl) Closed Channels; ${ }^{\mathrm{G} 1}$ acetylcholinesterase (AChE) enzyme inhibitor; ${ }^{\mathrm{G} 11}$ microbial insect gut disruptors.

\section{Results}

On the first day after contact caterpillars with treated bean leaves (1 DAI), the chemical treatments chlorphenapyr (288.0 $\mathrm{g}$ a.i./ha) and indoxacarb (120.0 g a.i./ha), followed by benzoate of emamectin $(10.0 \mathrm{~g}$ a.i./ha) achieved the highest shock effects to control $H$. armigera small caterpillars $(<1.5 \mathrm{~cm})$ compared to control and other treatments evaluated in the assay (Table 2). At three DAI, only flubendiamide treatments (72.0 $\mathrm{g}$ a.i./ha), chlorantraniliprole + lambda-cyhalothrin $(30.0+15.0 \mathrm{~g}$. a.i./ha) and B. thuringiensis $(500.0 \mathrm{~g}$ a.i./ha) did not show significant control to small caterpillars when compared to control, whereas other chemical treatments provided relatively high levels tocontrol, especially with chlorfenapyr treatment $(288.0 \mathrm{~g}$ a.i/ha) that presented $100 \%$ pest control (Table 2). At five and seven DAI, all chemical treatments showed significant control of small caterpillars in relation to the control treatment, without differing from each other. At seven DAI, there was no small caterpillar $(<1.5 \mathrm{~cm})$ surviving in the Petri dishes for all the chemical and biological treatments tested (Table 2).

As for the efficiency to control large caterpillars $(>1.5 \mathrm{~cm})$, in the first evaluation period (1 DAI), the chemical treatments chlorfenapyr (288.0 g a.i./ha), indoxacarb (120.0 g a.i./ha), and emamectin benzoate (10.0 g a.i./ha) obtained the lowest numbers of surviving caterpillars compared to control and similar to that observed for small caterpillars, providing control percentages of $60 \%, 55 \%$, and $70 \%$, respectively (Table 3). The other chemical and biological treatments evaluated had a number of surviving caterpillars similar to those observed in the control treatment for the first evaluation period (Table 3).

At three DAI, treatments flubendiamide $(72.0 \mathrm{~g}$ a.i./ha), chlorantraniliprole + lambda-cyhalothrin $(30.0+15.0 \mathrm{~g}$ a.i./ha), and B. thuringiensis (500.0 g a.i./ha) did not demonstrate significant control to large caterpillars compared to the control treatment, similarly to that observed for small caterpillars with these same treatments (Tables 2 and 3). In the other chemical treatments, higher levels of population reduction of large caterpillars were observed, with emphasis once again on the chlorphenapyr (288.0 g a.i./ha) and emamectin benzoate $(10.0 \mathrm{~g}$ a.i./ha) treatments, which obtained the highest control efficiencies of large caterpillars (Table 3). At five DAI, all chemical and biological treatments evaluated in the trial significantly reduced $H$. armigera large caterpillars' population in relation to the control treatment, with control levels ranging from $77.8 \%$ to $100.0 \%$. In the last mortality assessment performed in the trial $(7 \mathrm{DAI})$, all large $H$. armigera caterpillars were dead due to insecticide action, providing $100 \%$ mortality in all chemical or biological treatments tested (Table 3). 
Table 2. Average number of surviving small $(<1.5 \mathrm{~cm})$ Helicoverpa armigera (Hübner, 1805) caterpillars $(\mathrm{N})$ and percentage of control efficiency $(\mathrm{E} \%)$ at one, three, five, and seven days after treatment with different chemical and biological insecticides. Dourados/MS, 2019

\begin{tabular}{|c|c|c|c|c|c|c|c|c|c|}
\hline \multirow{2}{*}{ Treatments } & \multirow{2}{*}{$\begin{array}{l}\text { Dose } \\
\text { (g a.i./ha) }\end{array}$} & \multicolumn{2}{|l|}{$1 \mathrm{DAI}$} & \multicolumn{2}{|c|}{$3 \mathrm{DAI}$} & \multicolumn{2}{|c|}{$5 \mathrm{DAI}$} & \multicolumn{2}{|c|}{$7 \mathrm{DAI}$} \\
\hline & & $\mathrm{N}$ & $\mathrm{E}^{(\%)}$ & $\mathrm{N}$ & $\mathrm{E}^{(\%)}$ & $\mathrm{N}$ & $\mathrm{E}^{(\%)}$ & $\mathrm{N}$ & $\mathrm{E}^{(\%)}$ \\
\hline Flubendiamide & 72.0 & $4.5 \pm 0.6 \mathrm{abc}$ & 10.0 & $4.5 \pm 0.6 \mathrm{a}$ & 10.0 & $0.3 \pm 0.5 \mathrm{~b}$ & 95.0 & $0.0 \pm 0.0 \mathrm{~b}$ & 100.0 \\
\hline Chlorantraniliprole + lambda-cyhalothrin & $30.0+15.0$ & $4.5 \pm 0.6 \mathrm{abc}$ & 10.0 & $3.8 \pm 1.0 \mathrm{a}$ & 25.0 & $0.0 \pm 0.0 \mathrm{~b}$ & 100.0 & $0.0 \pm 0.0 \mathrm{~b}$ & 100.0 \\
\hline Chlorfenapyr & 288.0 & $1.3 \pm 1.0 \mathrm{~d}$ & 75.0 & $0.0 \pm 0.0 \mathrm{~b}$ & 100.0 & $0.0 \pm 0.0 \mathrm{~b}$ & 100.0 & $0.0 \pm 0.0 \mathrm{~b}$ & 100.0 \\
\hline Espinetoram & 18.0 & $2.5 \pm 0.6 \mathrm{bcd}$ & 50.0 & $0.8 \pm 1.0 \mathrm{~b}$ & 85.0 & $0.0 \pm 0.0 \mathrm{~b}$ & 100.0 & $0.0 \pm 0.0 \mathrm{~b}$ & 100.0 \\
\hline Indoxacarb & 120.0 & $1.5 \pm 1.0 \mathrm{~d}$ & 70.0 & $1.0 \pm 1.2 \mathrm{~b}$ & 80.0 & $0.0 \pm 0.0 \mathrm{~b}$ & 100.0 & $0.0 \pm 0.0 \mathrm{~b}$ & 100.0 \\
\hline Emamectin Benzoate & 10.0 & $2.3 \pm 1.3 \mathrm{~cd}$ & 55.0 & $0.5 \pm 0.6 \mathrm{~b}$ & 90.0 & $0.0 \pm 0.0 \mathrm{~b}$ & 100.0 & $0.0 \pm 0.0 \mathrm{~b}$ & 100.0 \\
\hline Metomil & 322.5 & $2.8 \pm 1.9 \mathrm{abcd}$ & 45.0 & $0.3 \pm 0.5 \mathrm{~b}$ & 95.0 & $0.0 \pm 0.0 \mathrm{~b}$ & 100.0 & $0.0 \pm 0.0 \mathrm{~b}$ & 100.0 \\
\hline Bacillus thuringiensis & 500.0 & $4.8 \pm 0.5 \mathrm{ab}$ & 5.0 & $4.8 \pm 0.5 \mathrm{a}$ & 5.0 & $0.0 \pm 0.0 \mathrm{~b}$ & 100.0 & $0.0 \pm 0.0 \mathrm{~b}$ & 100.0 \\
\hline Control & - & $5.0 \pm 0.0 \mathrm{a}$ & - & $5.0 \pm 0.0 \mathrm{a}$ & - & $3.8 \pm 0.5 \mathrm{a}$ & - & $3.8 \pm 0.5 \mathrm{a}$ & - \\
\hline $\mathrm{CV}(\%)$ & & 29.86 & & 30.46 & & 53.03 & & 40.00 & \\
\hline
\end{tabular}

Note. Means followed by the same letter in the column do not differ statistically from each other by the Tukey test $(\mathrm{p}<0.05)$.

DAI (Days after immersion).

Table 3. Average number of surviving large $(>1.5 \mathrm{~cm})$ larvae $(\mathrm{N})$ of Helicoverpa armigera (Hübner, 1805) and percentage of control efficiency $(\mathrm{E} \%)$ at one, three, five and seven days after treatment with different chemical and biological insecticides. Dourados/MS, 2019

\begin{tabular}{|c|c|c|c|c|c|c|c|c|c|}
\hline \multirow{2}{*}{ Treatments } & \multirow{2}{*}{$\begin{array}{l}\text { Dose } \\
\text { (g a.i./ha) }\end{array}$} & \multicolumn{2}{|c|}{$1 \mathrm{DAI}$} & \multicolumn{2}{|c|}{3 DAI } & \multicolumn{2}{|c|}{$5 \mathrm{DAI}$} & \multicolumn{2}{|c|}{7 DAI } \\
\hline & & $\mathrm{N}$ & $\mathrm{E}^{(\%)}$ & $\mathrm{N}$ & $\mathrm{E}^{(\%)}$ & $\mathrm{N}$ & $\mathrm{E}^{(\%)}$ & $\mathrm{N}$ & $E^{(\%)}$ \\
\hline Flubendiamide & 72.0 & $5.0 \pm 0.0 \mathrm{a}$ & 00.0 & $4.8 \pm 0.5 \mathrm{ab}$ & 5.0 & $1.0 \pm 0.8 \mathrm{~b}$ & 77.8 & $0.0 \pm 0.0 \mathrm{~b}$ & 100.0 \\
\hline Chlorantraniliprole+lambda-cyhalothrin & $30.0+15.0$ & $5.0 \pm 0.0 \mathrm{a}$ & 00.0 & $3.8 \pm 1.0 \mathrm{abc}$ & 25.0 & $0.8 \pm 1.0 \mathrm{~b}$ & 83.3 & $0.0 \pm 0.0 \mathrm{~b}$ & 100.0 \\
\hline Chlorfenapyr & 288.0 & $2.0 \pm 1.4 \mathrm{~b}$ & 60.0 & $0.0 \pm 0.0 \mathrm{e}$ & 100.0 & $0.0 \pm 0.0 \mathrm{~b}$ & 100.0 & $0.0 \pm 0.0 \mathrm{~b}$ & 100.0 \\
\hline Espinetoram & 18.0 & $3.5 \pm 1.9 \mathrm{ab}$ & 30.0 & $2.5 \pm 1.9 \mathrm{bcd}$ & 50.0 & $0.0 \pm 0.0 \mathrm{~b}$ & 100.0 & $0.0 \pm 0.0 \mathrm{~b}$ & 100.0 \\
\hline Indoxacarb & 120.0 & $2.3 \pm 1.0 \mathrm{~b}$ & 55.0 & $1.5 \pm 1.3 \mathrm{cde}$ & 70.0 & $0.5 \pm 0.6 \mathrm{~b}$ & 88.9 & $0.0 \pm 0.0 \mathrm{~b}$ & 100.0 \\
\hline Emamectin Benzoate & 10.0 & $1.5 \pm 1.0 \mathrm{~b}$ & 70.0 & $0.5 \pm 0.6 \mathrm{de}$ & 90.0 & $0.0 \pm 0.0 \mathrm{~b}$ & 100.0 & $0.0 \pm 0.0 \mathrm{~b}$ & 100.0 \\
\hline Metomil & 322.5 & $3.3 \pm 0.5 \mathrm{ab}$ & 35.0 & $1.8 \pm 1.3 \mathrm{cde}$ & 65.0 & $0.0 \pm 0.0 \mathrm{~b}$ & 100.0 & $0.0 \pm 0.0 \mathrm{~b}$ & 100.0 \\
\hline Bacillus thuringiensis & 500.0 & $5.0 \pm 0.0 \mathrm{a}$ & 00.0 & $4.8 \pm 0.5 \mathrm{ab}$ & 5.0 & $0.0 \pm 0.0 \mathrm{~b}$ & 100.0 & $0.0 \pm 0.0 \mathrm{~b}$ & 100.0 \\
\hline Control & - & $5.0 \pm 0.0 \mathrm{a}$ & - & $5.0 \pm 0.0 \mathrm{a}$ & - & $4.5 \pm 0.6 \mathrm{a}$ & - & $4.3 \pm 0.5 \mathrm{a}$ & - \\
\hline $\mathrm{CV}(\%)$ & & 25.84 & & 36.05 & & 66.67 & & 35.29 & \\
\hline
\end{tabular}

Note. Means followed by the same letter in the column do not differ statistically from each other by the Tukey test $(\mathrm{p}<0.05)$.

DAI (Days after immersion).

\section{Discussion}

Insecticides, both chemical and biological, are important tools to manage various pest insects to different crops. Those used to control $H$. armigera caterpillars can prevent economic damage in most crops where this species occurs. However, research evaluating the effectiveness of insecticides in controlling this pest has found different percentages of efficiency (Guedes et al., 2013; Chankapue et al., 2014). According to MAPA (2018), chemical and biological insecticides, released in Brazil, must control on average at least $80 \%$ of the target pests for the products to be considered agronomically efficient. Based on our results, all chemical and biological insecticides, tested with their respective doses, are efficient to control small and large $H$. armigera larvae, because by the last mortality evaluation performed in the assays (7 DAI), all H. armigera caterpillars (both sizes) had been killed due to insecticide action, providing $100 \%$ mortality.

The degree of control efficiency of a product is extremely important in the management of caterpillars, since in most cases spraying is performed almost as soon as a pest occurs in the crop, i.e., when small caterpillars predominate, to avoid greater damage to crops by large caterpillars (Cruz, 2002). However, the control efficiency may change due to the different developmental stages of the pest in the crop, and smaller sized caterpillars are 
generally more susceptible to insecticides (Gusmão et al., 2000; Basavanneppa \& Balikai, 2014; Abbas et al., 2015; Kuss et al., 2016). In field spraying, caterpillars receive more product on the integument, penetrating into the cuticle, trachea, or even pores, reaching the nervous system, and causing the death of the insect (Viana \& Costa, 1998; Fernandes et al., 2018). This work evaluated the control efficiency on both, small $(<1.5 \mathrm{~cm})$ and $(>$ $1.5 \mathrm{~cm}$ ) caterpillars, determining that the overall the size of the caterpillar had no influence on their susceptibility to the tested products.

The main chemical groups of insecticides applied to soybean crops, the primary host plant for H. armigera caterpillars in Brazil, are pyrethroids, organophosphates, and carbamates, which have been used for decades. However, benzoylureas and phthalic acid diamides have been used more recently (Hannig et al., 2009; Guedes et al., 2013; Tomquelski et al., 2015). Thus, at least five molecules (indoxacarb, chlorantraniliprole, chlorphenapyr, spinosad, and flubemdiamide) provide satisfactory control efficiency of $H$. armigera. These molecules represent products registered with different chemical groups, enabling the rotation of products due to the different mechanisms of action, which can prevent the development of insecticide resistant populations (Corrêa-Ferreira et al., 2014). It is well known that $H$. armigera is a species that can easily develop populations resistant to commercially available insecticide (Fathipour \& Sedaratian, 2013).

Even though no statistical differences between the sizes of caterpillars and the products tested were found during the evaluations, the ones with the lowest shock effect were flubendiamide, cyantraniliprole + lambdacialotrin, and B. thuringiensis. This can be partially explained by the fact that flubendiamide is a newly discovered group, and there are few studies conducted to evaluate its effectiveness in controlling $H$. armigera caterpillars. However, the results generated in this research may contribute to these clarifications.

The mode of action is related to the active ingredient in each product. The chemical insecticides of the diamide group (flubendiamide and chlorantraniliprole) when in contact with the insect binds to the ryanodine receptors on muscle cells, causing calcium channels to open, leading initially the cessation of feeding, paralysis, and posteriorly its death (Cordova et al., 2006; Lahm et al., 2007; Arrue et al., 2014). In this way, the mode of action of diamids explains the delayed shock effect observed for both small and large caterpillars. Chlorantraniliprole is an important insecticide in the diamide group (IRAC, 2019), that presents low toxicity to other animals such as natural enemies, mammals, birds, and fish (Lahm et al., 2007; Larson et al., 2012). Flubendiamide is another insecticide in the same group that also causes slower mortality of target insects (Lima-Neto, 2016), as was also observed in the results obtained in this study for second and fourth instar caterpillars.

For the only biological insecticide tested B. thuringiensis, studies have showed that first and second instar small caterpillars $(<1.5 \mathrm{~cm})$ die one week after application (Salvadori et al., 2013), corroborating the low mortality of H. armigera observed in the first evaluations for both caterpillar sizes. This low control efficiency, after exposure to caterpillars, could be related to its mechanism of action, because this product affects the intestinal epithelium, interrupting caterpillar feeding within hours after exposure, but not causing the immediate death of caterpillars in the early phase of contamination (Bueno et al., 2012), as also was observed for the tested insecticides of the diamide group.

An important characteristic for insecticides, in addition to their efficiency, is their residual period, which decreases the number of required applications and costs, consequently, increasing the plant protection period, as observed in all insecticide treatments in this research after five DAI for both, small and large caterpillars. Regarding the shock effect, the chlorphenapyr (288.0 g a.i./ha) and indoxacarb (120.0 g a.i./ha) insecticides were more effective, especially for small caterpillars, when they presented $75 \%$ and $70 \%$ of control, respectively, in 24 hours (Table 2). The results obtained in this work with these products also showed good control of large $H$. armigera caterpillars together with emamectin benzoate treatment (10.0 g a.i./ha), which corroborates the results presented by Perini et al. (2016); Kuss et al. (2016); Sandip and Arunava (2018), which obtained similar results with chlorphenapyr for $H$. armigera control. In general, the control of $H$. armigera reached $100 \%$ mortality level at seven DAI for both, small and large caterpillars with different insecticides used. Thus, these products present a promising alternative to control caterpillars of this pest by producers. Furthermore, according to the results obtained here, the control of $H$. armigera with biological products can be also viable, as the results obtained with $B$. thuringienses were quite satisfactory. However, successful control of any type of pest must include the proper pest monitoring in the area, rotation of products with different active ingredient, and selection of insecticides that preserve natural enemies and environment, which are fundamental principles of the Integrated Pest Management.

\section{Conclusions}

All chemical and biological insecticides tested in this study are efficient to control H. armigera caterpillars, not only in the early phase of development, but also for the most developed caterpillars. 


\section{References}

Abbas, G., Hassan, N., Farhan, M., Haq, I., \& Karar, H. (2015). Effect of selected insecticides on Helicoverpa armigera Hubner (Lepidoptera: Noctuidae) on tomato (Lycopersicon esculentum Miller) and their successful management. Advances in Entomology, 3, 16-23. https://doi.org/10.4236/ae.2015.31003

Abbott, W. S. (1925). A method of computing the effectiveness of an insecticide. Journal of Economic Entomology, 18, 265-267. https://doi.org/10.1093/jee/18.2.265a

Abdul, R., Saeed, H. A., Akhtar, L. H., Siddiq, S. Z., \& Arshid, M. (2003). Comparative efficacy of various insecticides to control gram pod borer (Helicoverpa armigera) on chick pea. Asian Journal Plant Science, 2, 403-405, https://doi.org/10.3923/ajps.2003.403.405

Ahmad, M., Arif, M. I., \& Ahmad, Z. (2001). Resistance to carbamate insecticides in Helicoverpa armigera (Lepidoptera: Noctuidae) in Pakistan. Crop Protection, 20, 427-432. https://doi.org/10.1016/S0261-2194 (00)00168-X

Arrue, A., Guedes, J. V. C., Storck, L., Swarowsky, A., Cagliari, D., Burtet, L. M., \& Arnemann, J. A. (2014). Precipitação artificial após aplicação do inseticida clorantraniliprole associado com adjuvante em plantas de soja. Ciência Rural, 44, 2118-2123. https://doi.org/10.1590/0103-8478cr20120211

Ávila, C. J., Vivan, L. M., \& Tomquelski, G. V. (2013). Ocorrência, aspectos biológicos, danos e estratégias de manejo de Helicoverpa armigera (Hübner) (Lepidoptera: Noctuidae) nos sistemas de produção agrícolas (Circular Técnica, 23, p. 12). Dourados: Embrapa Agropecuária Oeste.

Avilla, C., \& González-Zamora, J. E. (2010). Monitoring resistence of Helicoverpa armigera to different insecticides used in cotton in Spain. Crop Protection, 29, 100-103, https://doi.org/10.1016/j.cropro.2009. 09.007

Babariya, P. M., Kabaria, B. B., Patel, V. N., \& Joshi, M. D. (2010). Chemical control of gram pod borer, Helicoverpa armigera Hubner infesting pigeonpea. Legume Research, 33, 224-226.

Basavanneppa, B. B., \& Balikai, R. A. (2014). Toxicity of newer insecticides against Helicoverpa armigera (Hubner) under laboratory condition. International Journal of Agricultural and Statistical Sciences, 10, 221-223.

Brévault, T. (2009). Initial activity and persistence of insecticides for the control of bollworms (Lepidoptera: Noctuidae) in cotton crops. Crop Protection, 28, 401-406. https://doi.org/10.1016/j.cropro.2008.12.006

Bueno, A. F., Sosa-Gómez, D. R., Corrêa-Ferreira, B. S., Moscardi, F., \& Bueno, R. C. O. F. (2012). Inimigos naturais das pragas da soja. In C. B. Hoffmann-Campo, B. S. Corrêa-Ferreira, \& F. Moscardi (Eds.), Soja: Manejo integrado de insetos e outros artrópodes-praga (pp. 493-629). Brasília: Embrapa.

Cordova, D., Benner, E. A., Sacher, M. D., Rauh, J. J., Sopa, J. S., Lahm, G. P., \& Selby, T. P. (2006). Anthranilic diamides: A new class of insecticides with a novel mode of action, ryanodine receptor activation. Pesticide Biochemistry Physiology, 84, 196-214. https://doi.org/10.1016/j.pestbp.2005.07.005

Cruz, I. (2002). Manejo da resistência de insetos-praga a inseticidas, com ênfase em Spodoptera frugiperda (Smith) (p. 15). Sete Lagoas: Embrapa Milho e Sorgo.

Cunningham, J. P., \& Zalucki, M. P. (2014). Understanding Heliothine (Lepidoptera: Heliothinae) pests: What is a host plant? Journal of Economic Entomology, 107, 881-896. https://doi.org/10.1603/EC14036

David, A. H. M., Lloyd, R. J., \& Hopkinson, J. E. (2005). Efficacy of new pesticide for management of Helicoverpa spp. in Australian grain crops. Australian Journal Entomolgy, 44, 62-78, https://doi.org/ 10.1111/j.1440-6055.2005.00422.x

EMBRAPA. (2013). Alerta Helicoverpa: Ações emergenciais propostas pela embrapa para o manejo integrado de Helicoverpa spp. em áreas agrícolas. Retrieved from http://www.embrapa.br/alerta-helicoverpa

Fathipour, Y., \& Sedaratian, A. (2013). Integrated management systems of cultivation of soy Helicoverpa armigera. In H. A. Elshemy (Ed.), Resistance a Pests of Soybeans (pp. 231-280). InTeOpP: Cairo, Egypt. https://doi.org/10.5772/54522

Fernandes, F. O., Abreu, J. A., Christ, L. M., \& Rosa, A. P. S. A. (2018). Efficacy of Insecticides Against Spodoptera frugiperda (Smith, 1797). Journal of Agricultural Science, 11(1), 494. https://doi.org/10.5539/ jas.v11n 1 p494 
Guedes, J. V. C., Arnemann, J. A., Perini, C. R., Melo, A. A., Rohrig, A., Stacke, R. F., \& Machado, M. R. R. (2013). Helicoverpa armigera da invasão ao manejo na soja. Revista Plantio Direto, 24-35.

Gusmão, M. R., Picanço, M., Gonring, A. H. R., \& Moura, M. F. (2000). Seletividade fisiológica de inseticidas a vespidae predadores do bicho-mineiro-do-cafeeiro. Pesquisa Agropecuária Brasileira, 35, 681-686, https://doi.org/10.1590/S0100-204X2000000400002

Hannig, G. T., Ziegler, M., \& Marçon, P. G. (2009). Feeding cessation effects of chlorantraniliprole, a new anthranilic diamide insecticide, in comparison with several insecticides in distinct chemical classes and mode-of-action groups. Pest Management Science, 65, 969-974. https://doi.org/10.1002/ps.1781

Kuss, C. C., Roggia, R. C. R. K., Basso, C. J., Oliveira, M. C. N., Pias, O. H. C., \& Roggia, S. (2016). Controle de Helicoverpa armigera (Lepidoptera: Noctuidae) em soja com inseticidas químicos e biológicos. Pesquisa Agropecuária Brasileira, 51, 527-536, https://doi.org/10.1590/S0100-204X2016000500013

Lahm, G. P., Stevenson, T. M., Selby, T. P., Freudenberger, J. H., Cordova, D., Flexner, L., \& Benner, E. A. (2007). Rynaxypyr(tm): A new insecticidal anthranilic diamide that acts as a potent and selective ryanodine receptor activator. Bioorganic \& Medicinal Chemistry Letters, 17, 6274-6279. https://doi.org/10.1016/ j.bmcl.2007.09.012

Lima Neto, J. E., \& Siqueira, H. Á. A. (2017). Seleção de Plutella xylostella (L.) (Lepidoptera: Plutellidae) para resistência a clorfenapir: Herdabilidade e o número de genes envolvidos. Rev. Caatinga, 30, 1067-1072. https://doi.org/10.1590/1983-21252017v30n428rc

MAPA (Ministério da Agricultura, Pecuária e Abastecimento). (2018). Memória da $2^{a}$ reunião técnica nacional sobre pesquisa com agrotóxicos (pp. 1-6). Brasília, Brazil.

Mironidis, G. K., \& Savopoulou-Soultani, M. (2009). Development, survival and growth rate of the Hyposoter didymator Helicoverpa armigera parasitoid-host system: Effect of host instar at parasitism. Biological Control, 49, 58-67, https://doi.org/10.1016/j.biocontrol.2008.12.006

Naseri, B., Fathipour, Y., Moharramipour, S., \& Hosseininaveh, V. (2009a). Comparative life history and fecundity of Helicoverpa armigera (Hubner) (Lepidoptera: Noctuidae) on different soybean varieties. Entomological Science, 12, 147-154. https://doi.org/10.1111/j.1479-8298.2009.00310.x

Naseri, B., Fathipour, Y., Moharramipour, S., \& Hosseininaveh, V. (2009b). Life Table parameters of the cotton bollworm, Helicoverpa armigera (Lep.: Noctuidae) on different soybean cultivars. Journal of Entomological Society of Iran, 29, 25-40.

Noorani, A. M., Shah, A. D., Jugnati, T. K., \& Lohar, M. K. (1994). Efficacy of different insecticides against gram pod borer (Helicoverpa armigera) on gram crop under field condition. Sarhad Journal of Agriculture, 7, 183-186.

Perini, C. R., Amemann, J. A., Melo, A. A., Pes, M. P., Valmorbida, I., Beche, M., \& Guedes, J. V. C. (2016). How to control Helicoverpa armigera on soybean in Brasil? What we have learned since its detection. African Journal of Agricultural Research, 11, 1426-1432. https://doi.org/10.5897/AJAR2016.10903

Salvadori, J. R., \& Pereira, P. R. V. S. (2013). Specht, A. Helicoverpa armigera no Sul. Cultivar Grandes Culturas, 176, 22-23.

Sandep, S., Khandwe, N., \& Nema, K. K. (2014). Chemical conttrol of Helicoverpa armigera (Hubner) in Chick pea. Plant Protection Sciences, 22, 85-87.

Sandip, P., \& Arunava, S. (2018). Evaluation of insecticides against Helicoverpa armigera and Spodoptera litura in tomato. Indian Journal of Entomology, 80. https://doi.org/10.5958/0974-8172.2018.00263.8

Shivana, B. K., Lathia, M., Jeevitha, S., Chethan, K. S., \& Priyanka, K. (2014). Management of budworn, Helicoverpa armigera (Hubner) whit new molecules and its effect on yield in FCV tobacco. Environment and Ecology, 32, 129-133.

Silva, I. F., Baldin, E. L. L., Specht, A., Sosa-Gómez, D. R., Roque-Specht, V. F., Morando, R., \& Paula-Moraes, S. V. (2018). Biotic potential and life table of Helicoverpa armigera (Hübner) (Lepidoptera: Noctuidae) from three Brazilian regions. Neotropical Entomology, 47, 344-351. https://doi.org/10.1007/s13744-0170529-8

Thilagam, P., Sivasubramanian, P., \& Kuttalam, S. (2010). Bioefficacy of Flubendiamide 480 SC against American bollworm in Cotton and Biochemical changes. Annals of Plant Protection Sciences, 18, 384-387. 
Tomquelski, G. V., Martins, G. L. M., \& Dias, T. S. (2015). Características e manejo de pragas da cultura da soja. Pesquisa, Tecnologia e Produtividade, 2, 61-82.

Viana, P. A., \& Costa, E. F. (1998). Controle da lagarta-do-cartucho, Spodoptera frugiperda (J. E. Smith) (Lepidoptera: Noctuidae) na cultura do milho com inseticidas aplicados via irrigação por aspersão. Anais da Sociedade Entomológica do Brasil, 27(3), 451-458. https://doi.org/10.1590/S0301-80591998000300014

Vieira, M. C. S., Vieira, E. C. S., Gomes, E. S., Silva, I. F., Silva, P. G., Ávila, C. J., \& Oliveira, H. N. (2018). Criação de Helicoverpa armigera (Hübner) (Lepidoptera: Noctuidae: Heliothinae) em condições de laboratório utilizando dietas artificial e natural (Circular técnica, 46, p. 17). Dourados: Embrapa Agropecuária Oeste.

\section{Copyrights}

Copyright for this article is retained by the author(s), with first publication rights granted to the journal.

This is an open-access article distributed under the terms and conditions of the Creative Commons Attribution license (http://creativecommons.org/licenses/by/4.0/). 